\title{
Floating synthetic filtering device development for turbidity value reduction of water in Eshkakon reservoir
}

\author{
Tatiana Ivankova ${ }^{1, *}$ \\ ${ }^{1}$ Academy of Safety of Hydraulic Structures, 346421, Novocherkassk, Russia
}

\begin{abstract}
This paper presents multifactorial studies to solve the improving water quality problem where effective filtering devices development is relevant. Intake filters perform primary treatment - retain water suspension and debris of anthropogenic origin. Water analysis monitoring of the Eshkakon reservoir has been presented, as a result there is a need to use a filtration device to reduce its turbidity. A comparative analysis of material, construction and operating costs of various types of water intakes is given and the most economical and prospective one, composed of soft floating filtering devices made of synthetic fabrics, is identified. The main purpose of the device is to reduce "mud load", mechanical pre-treatment of fresh water until entering a water treatment plant (WTP), water purification from plankton and suspended particles. The main element of the device is a filter wall made of flexible polypropylene material, which makes selective water intake. Advantages of the device include flexibility, high short-term and long-term strength, rot proofing; compliance of the filter design with effective fish protection devices; economic effect of advent of technology is to reduce investment in its manufacture, material consumption and labor costs in operational cycle.
\end{abstract}

\section{Introduction}

Water management development is accompanied by new technologies, structures and materials, makes it possible to modernize and reconstruct existing hydraulic structures [1]. Among the most pressing challenge of Russian water sector are:

- deterioration of nearly all previously constructed head structures and their reconstruction [2];

- water quality improving for irrigation and water supply [3].

The study was performed to solve improving water quality issue, where development of effective filtering devices made of modern synthetic materials is relevant. Intake filters must perform mechanical cleaning - retain water suspension and debris of anthropogenic origin. Filter is one of the main elements in water intake devices, which ensures that water is supplied to the pre-pump containers, which is maximally purified from adulterants. Currently, mainly water receivers are used - tubular, traction, concrete and reinforced

\footnotetext{
* Corresponding author: academy-design@mail.ru
} 
concrete. In the forest zone of the European part of Russia, where rivers and lakes turbidity is not large, tube and drum filters are used [4]. In the forest-steppe and steppe zones of Russia, water intake units with settling tanks and more complex filtering devices are used. This is due to the increased turbidity of river water, caused mainly by surface flushing of the soil layer. The turbidity of river water in the steppe zone is especially high, with arable land reaching $90 \%$ of the area. For example, in the lower reaches of the Don River, the turbidity of water exceeds the MPC $(1.5 \mathrm{mg} / \mathrm{l})$ by a factor of ten; in 1994, an excess of 160 times was recorded [5]. A comparative analysis of the cost of materials, construction and operating costs of various types of water intakes showed that the most economical and, therefore, promising is the creation of soft floating filtration devices made of synthetic fabrics. Comprehensive studies of soft surfacing structures in the period 1973-2008 performed by specialists of the Novocherkassk Hydrotechnical Scientific School. Their methods of calculation, development and improvement of structures with water protection functions are summarized in the monograph [6], the results of theoretical and field studies of a soft surfacing structure made of nylon fabrics with double-sided rubber coating as applied to the intake of a pumping station from a canal (Ukrainian SSR) are given [7,8]. The Azerbaijan Scientific Research Institute of Water Problems for water intakes on rivers with high turbidity has developed a water intake-clarifier with complex structure filter, which is attached to metal pontoons [9]. We offer an improved version based on Novocherkassk-type filter - floating synthetic filter device (FSFD).

\section{Materials and Methods}

Selective water intake is possible if there is a vertical planar stratification in the reservoir. Multivariable studies of the Eshkakon reservoir confirmed formation of vertical density stratification in it due to seasonal fluctuations in air temperature and muddy water inflow the reservoir.

The construction is designed for a daily intake of 170 thousand m3. Actual water withdrawal in 2010-2015 amounted to 60 thousand m3 / day. The Eshkakon hydroelectric plant supplied more than 715 million $\mathrm{m} 3$ of water for about 25 years of operation [10]. The water intake of the Eshkakon reservoir has 3 windows at $1212.00 \mathrm{~m} ; 1,185.00 \mathrm{~m} ; 1172.60$ $\mathrm{m}$ (crest level $1214.5 \mathrm{~m}$ ). Actual daily water supply is $0.694 \mathrm{~m} 3 / \mathrm{s}$. The annual water supply over the past 15 years' ranges from 25.15 million $\mathrm{m} 3$ / year to 32.14 million $\mathrm{m} 3$ / year, depending on the humidity of the year. Water in the Eshkakon reservoir has a low temperature of $4-15^{\circ} \mathrm{C}$ during the year, which protects the reservoir from overgrowing. The content of free carbon dioxide does not exceed $1.4 \mathrm{mg} / \mathrm{l}$; iron does not exceed $0.4 \mathrm{mg}$ / 1; in terms of hardness, water is moderately hard $2.86-5.72 \mathrm{mEq} / \mathrm{L}$. Surfactants, organic and phenolic compounds, arsenic and oil products in the water are completely absent, therefore, service water and industrial wastewater does not fall into the reservoir [11]. Suspension concentration varies from 0 to $1.6 \mathrm{mg} / 1$ in the autumn-winter months, from 4 to $18 \mathrm{mg} / 1$ (March, July, August), and in April, May, June - from $4 \mathrm{mg} / 1$ to $150 \mathrm{mg} / 1$ (see table 1).

Table 1. Concentration of suspended solids in the Eshkakon reservoir within a year (water withdrawal).

\begin{tabular}{|c|c|c|c|}
\hline $\mathbf{N}$ & Monitoring period & Turbidity, mg / I & $\begin{array}{c}\text { Temperature, } \\
\text { C }^{0}\end{array}$ \\
\hline \multicolumn{4}{|c|}{1995 year } \\
\hline \multirow{3}{*}{1} & January, February, March (I quarter of the year) & $0-11-24$ & $4-3-3$ \\
\hline & April, May, June (II quarter of the year) & $50-80-4$ & $4-8-9$ \\
\hline & July, August, September (III quarter) & $3,6-1,5-0,75$ & $10-13-10$ \\
\hline
\end{tabular}




\begin{tabular}{|c|c|c|c|}
\hline & October, November, December (IV quarter) & $0,6-1,75-0$ & $8-5-4$ \\
\hline \multicolumn{4}{|c|}{1997 year } \\
\hline \multirow{4}{*}{3} & January, February, March (I quarter of the year) & $0-5-18$ & $3-4-4$ \\
\hline & April, May, June (II quarter of the year) & $48-120-80$ & $5-7-10$ \\
\hline & July, August, September (III quarter) & $20-5-3$ & $11-12-13$ \\
\hline & October, November, December (IV quarter) & $2-0-0$ & $12-7-5$ \\
\hline \multicolumn{4}{|c|}{1998 year } \\
\hline \multirow{4}{*}{4} & January, February, March (I quarter of the year) & $0-0-4$ & $3-4-5$ \\
\hline & April, May, June (II quarter of the year) & $25-85-170$ & $6-8-9$ \\
\hline & July, August, September (III quarter) & $80-20-8$ & $10-11-12$ \\
\hline & October, November, December (IV quarter) & $3-0-0$ & $10-6-4$ \\
\hline \multicolumn{4}{|c|}{2019 year } \\
\hline \multirow{4}{*}{5} & January, February, March (I quarter of the year) & $0-4-20$ & $4-4-3$ \\
\hline & April, May, June (II quarter of the year) & $42-85-150$ & $7-10-7$ \\
\hline & July, August, September (III quarter) & $15-5-2$ & $10-12-11$ \\
\hline & October, November, December (IV quarter) & 3 & 10 \\
\hline
\end{tabular}

According to GOST R 51232-98 [12], amount of suspended solids in the water supplied by water pipelines for drinking purposes by centralized water pipelines is not more than 1.5 $\mathrm{mg} / \mathrm{l}$. Based on the results of water analyzes in the water intake section of the Eshkakon reservoir, suspension content and water temperature graphs within a year were constructed (Figs. 1 and 2):

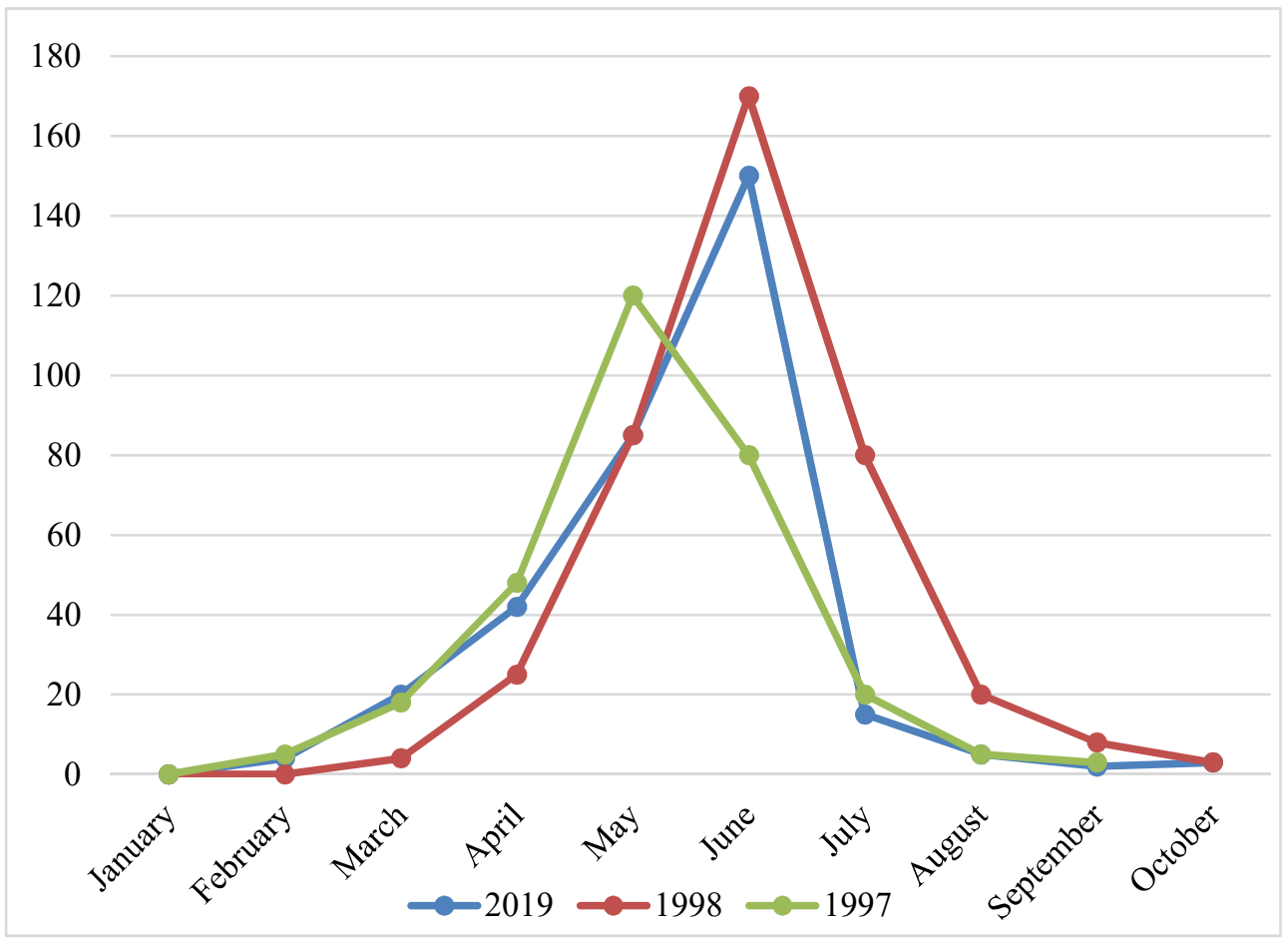

Fig. 1. Diagram of turbidity in the Eshkakon reservoir in a year.

The performed studies revealed needs to reduce turbidity of the water. This is possible in two ways: by adding coagulant or by installing filters. The average amount of coagulant required in a year was calculated: with a turbidity of the initial water of $20 \mathrm{mg} / 1$ and a color of 5 degrees. The technological scheme was adopted according to turbidity according to [8] SP 31.13330.2012: DK $=35 \mathrm{mg} / \mathrm{L}$, according to color unit: $\mathrm{DK}=4 \sqrt{\mathrm{C}}=4 \sqrt{5}=9$ 
$\mathrm{mg} / \mathrm{L}$. If the suspension and color are contained in water, we take the largest of the doses: $35 \mathrm{mg} / 1$. According to remarks 2 to the table 13 of SP 31.13330.2012, we reduce the accepted dose by $10 \%$ so we get $32 \mathrm{mg} / 1$.

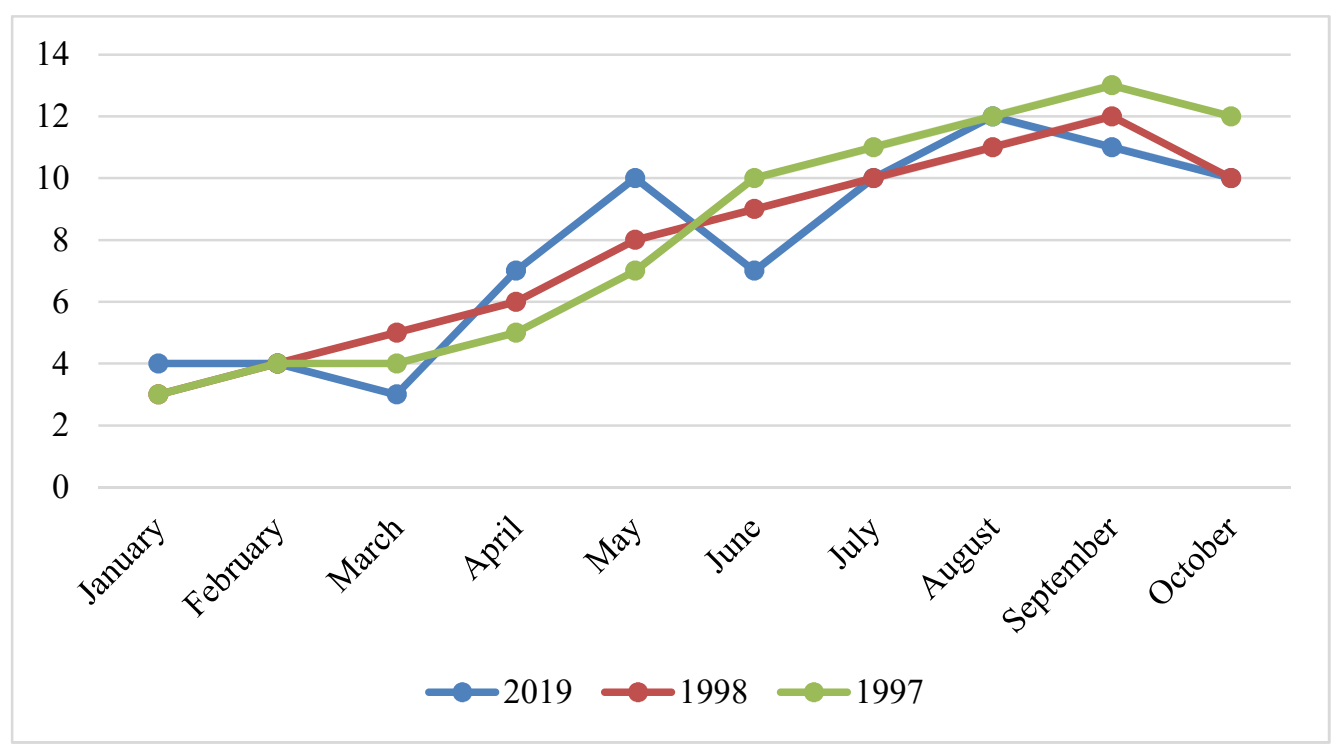

Fig. 2. Water temperature changing in the Eshkakon reservoir.

With water turbidity up to $100 \mathrm{mg} / 1$ and a flow rate of 60 thousand $\mathrm{m} 3 /$ day $(2.5$ thousand $\mathrm{m} 3 / \mathrm{h}=2500000 \mathrm{l} / \mathrm{h})$ the coagulant consumption is $81 / \mathrm{h}(1921 /$ day). For 60 thousand $\mathrm{m} 3$ / day we need about $0.192 \mathrm{~m} 3$ / day coagulant or $70.8 \mathrm{~m} 3$ / year $(70,0001$ / year). The average coagulant price ("Aurat") is 80 rubles / liter, so 5 million 600 thousand rubles are spent on a reagent per year. By reducing the mud load by $40 \%$, we get decrease in the reagent by the same percentage, which gives an economic benefit of 2 million 240 thousand rubles [13]. Polypropylene fiber and fabric made from it has the following characteristics:

- relative deformation - tensile ( $\varepsilon 1$ and $\varepsilon 2)$ in working condition can reach $10 \%, 15 \%$; fracture occurs when tensile is over $30 \%$.

Main stresses T1, $(\mathrm{kPa}), \mathrm{T} 2(\mathrm{kPa})$ in the polypropylene fabric material in the final deformed state were determined by numerical methods (Figure 3 ).
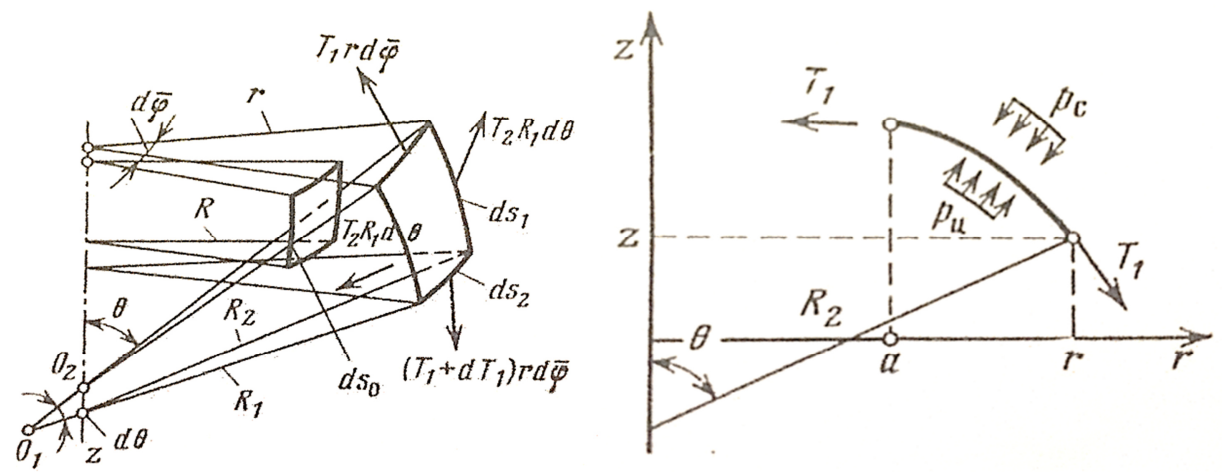

Fig. 3. Main stresses in the fabric material. 
The main meridional stresses $(\sigma 1=\mathrm{T} 1 / \mathrm{t} 1, \mathrm{Kpa})$, where $\mathrm{t} 1$ is the thickness of the polypropylene filaments in the meridional direction, $\mathrm{mm}$; $\mathrm{t} 2$ - the thickness of the polypropylene yarns in the annular direction, $\mathrm{mm}$.

Main ring stresses, Kpa) are calculated by the expressions:

$$
\begin{gathered}
\mathrm{T}_{1}=\frac{\Delta P}{2 r * \sin \theta} \\
\mathrm{T}_{2}=\frac{\frac{1}{R 1 * \cos \theta} * d}{d \theta}
\end{gathered}
$$

Strength conditions for fabric material:

$$
\sigma_{1}^{\max } \leq R_{1}, \sigma_{2}^{\max } \leq R_{2}
$$

Allowable stress $\left[\mathrm{T}_{1}, \frac{k N}{m} ; \frac{k N}{m} ;\right]$

depend on relative deformations in the main directions ( $\varepsilon 1$ and $\varepsilon 2)$

$$
\begin{gathered}
\mathrm{T}_{1}=\mathrm{f} 1\left(\varepsilon_{1}, \varepsilon_{2}\right), \mathrm{T}_{2}=\mathrm{f} 1\left(\varepsilon_{1}, \varepsilon_{2}\right) \\
R_{1}^{\text {dop }}=\frac{T_{1}}{t_{1} * \varphi} ; R_{2}=\frac{T_{2}}{t_{2} * \varphi} \text { experimental verification, }
\end{gathered}
$$

where $\varphi$ - reliability coefficient taking into account long-term strength (its reduction), taking into account dynamic loads, manufacturing technology; $\varphi \in[1,5 \ldots 2,5]$.

In the technical conditions for polypropylene fabric materials, the maximum values of permissible stresses R1 and R2 are given according to the results of tensile testing of 50 * $200 \mathrm{~N}$ (table. 2):

Table 2. Results of the tests of polypropylene fiber tensile.

\begin{tabular}{|c|c|c|c|c|}
\hline $\mathbf{N}$ & Item name & Area density, $\mathbf{g} / \mathbf{m}^{\mathbf{2}}$ & Basis & Textiles woof \\
\hline 1 & KS -34 & $437 \pm 20$ & 2400 & 1600 \\
\hline 2 & KS-44 & $566 \pm 28$ & 3000 & 1600 \\
\hline 3 & PP Atlas & $250 \pm 13$ & 3000 & 1200 \\
\hline 4 & Sahara 7 & $310 \pm 15$ & 2400 & 4700 \\
\hline
\end{tabular}

For manufacture of floating synthetic filter device (FSFD) technical polymer fabrics are used, which does not violate environmental situation and reduces economic expenditures of clearing riverbeds. The device purpose is to reduce "mud load", mechanical pre-treatment of fresh water before entering waste treatment facilities, water purification from plankton and suspended particles [14].

The main element of the device is a filter wall made of flexible polypropylene material, which allows selective water intake. The layout of the FSFD applied to the Eshkakon water intake is shown in Figure 4. 


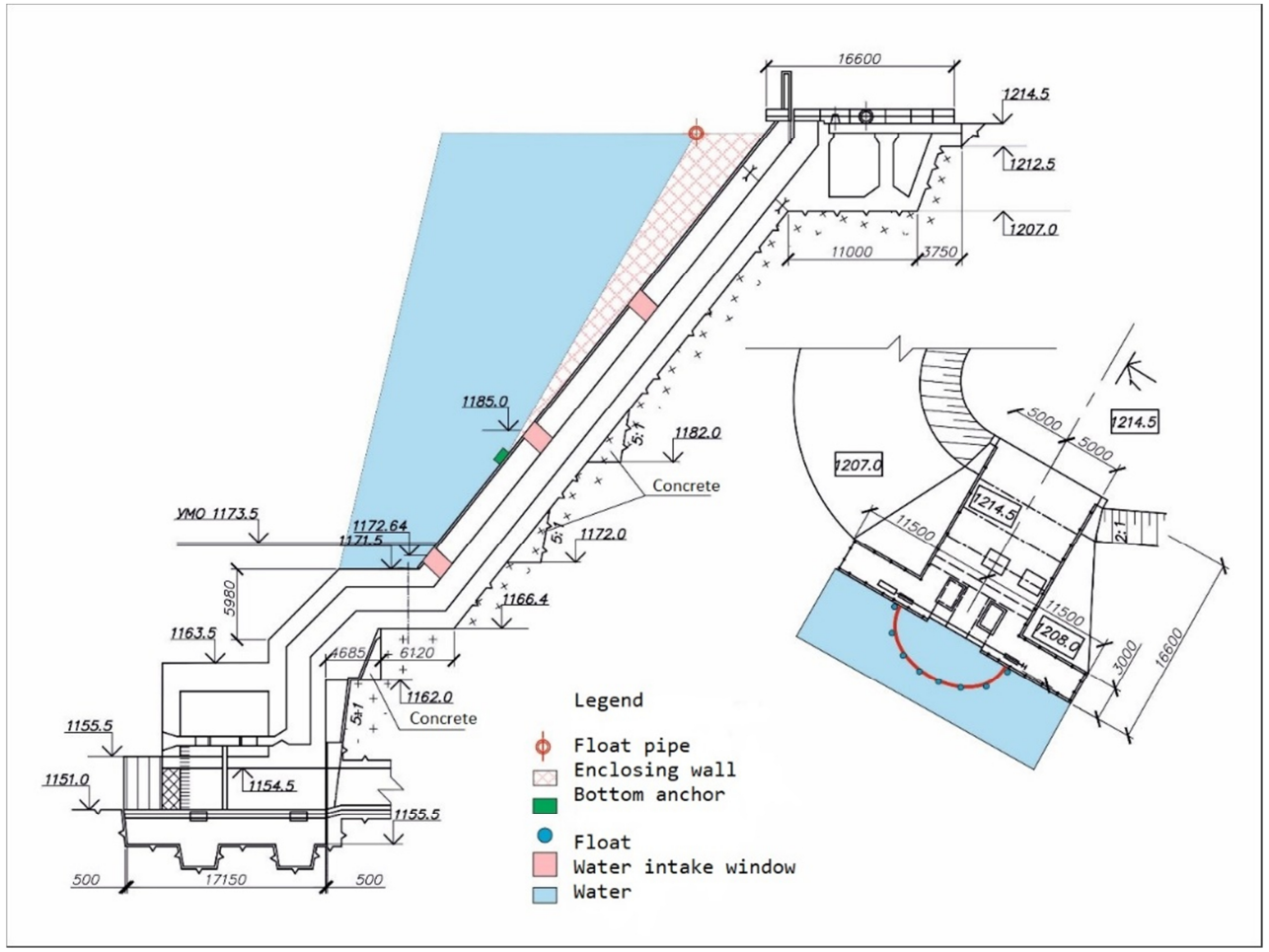

Fig. 4. Developed FSFD applicable to Eshkakon catchment.

The float pipe (1) keeps the enclosing wall (2) (polypropylene fiber) afloat. The enclosing wall (2) is made of polypropylene material of a given thoroughness; its upper part is attached to the float (1), and the lower part to the bottom anchor (3). When FSFD is operated, the lifting force of the float (1) provides the rise (lowering) of the flexible continuous panel of the wall. The height of the wall (2) is chosen so that the enclosed water area is separated from the reservoir at any level of the water horizon. The bottom anchors (3) are bags made of synthetic fabric into which sand pulp is pumped. The device operates as follows: intake structure has three windows located along the depth of the water in the reservoir. The first two windows are working; the third window is silted. In this connection, it is not cost-effective to place FSFD below the mark of the second water intake window. With the passage of flood waters, water turbidity in the water body increases. The device allows you to hold floating bodies, algae, plankton and perform functions of fish protection structures. After a certain operation period of the device, it is flushed hydraulically. The advantages of the device include: flexibility, high short-term and long-term strength, rot resistance; compliance of the filter design with effective fish protection devices; economic effect of the introduction is to reduce investment in its manufacture, material consumption and labor costs during operation period. The economic feasibility of developing FSFD are shown in table 3, the comparative analysis is given with an analogue of nylon fabrics with a rubberized coating.

Table 3. Economic feasibility of the developed device and its analog.

\begin{tabular}{|c|l|l|}
\hline $\mathbf{N}$ & \multicolumn{2}{|c|}{ Item name } \\
\hline 1 & $\begin{array}{l}\text { A device is made of high-strength fabric } \\
\text { materials with a variable thoroughness and } \\
\text { various diameters of the warp yarn and }\end{array}$ & Device (analog) \\
\hline
\end{tabular}




\begin{tabular}{|c|c|c|}
\hline & textiles woof & \\
\hline 2 & $\begin{array}{l}\text { An individual factory-made polypropylene } \\
\text { fabric cloth with a variable thoroughness in } \\
\text { depth }-30 \times 10 \mathrm{~m}=220 \text { rubles } / \mathrm{m} 2 * 300 \\
\mathrm{~m} 2=66,000 \text { rub. }\end{array}$ & $\begin{array}{l}\text { Fabric based on TK- } 100 \text { nylon threads } \\
\text { with a rubber factory coating }-200 \mathrm{~m} 2 * \\
200 \mathrm{~m} 2=250,000 \text { rub. }\end{array}$ \\
\hline 3 & $\begin{array}{l}\text { Flexible corrugated pipe D } 160 \mathrm{~mm} \\
\text { polyethylene PND PVD polypropylene PP } \\
-70 \text { rubles. } / \mathrm{m}=70 * 10 \mathrm{~m}=700 \text { rub. }\end{array}$ & $\begin{array}{l}\text { A metal pipe } \mathrm{D} 200 \mathrm{~mm} \text { with a wall } \\
\text { thickness of } 10 \mathrm{~mm} \text { with a corrosion- } \\
\text { resistant coating } \mathrm{L}=40 \mathrm{~m}=60,000 \mathrm{rub} \text {. }\end{array}$ \\
\hline 4 & $\begin{array}{l}\text { Transparent metal-polymer cable } \mathrm{PR}-6.0 \text {, } \\
(6.0 \mathrm{~mm} \text { thickness, coil } 150 \text { m.p. }) \text { SibrTech } \\
476403000 \mathrm{rub}+\text { Cable type braces } 4000 \\
\text { rub }=7000 \mathrm{rub}\end{array}$ & $\begin{array}{l}\text { Metal cable with a protective anti- } \\
\text { corrosion coating for braces } \mathrm{D} 10 \mathrm{~mm}, \mathrm{~L} \\
30 \mathrm{~m}=34000 \text { rub. }\end{array}$ \\
\hline 5 & & $\begin{array}{l}\text { Reinforced concrete anchor supports } 160 \\
\text { pcs. weighing } 80 \mathrm{~kg} \text { each }=110,000 \mathrm{rub} \text {. }\end{array}$ \\
\hline 6 & TOTAL: 73700 rub. (prime cost) & $\begin{array}{l}\text { TOTAL: } 454000 \text { rub. } \\
\text { (prime cost) }\end{array}$ \\
\hline
\end{tabular}

At this stage kapron fiber brands (analog) and variations of polypropylene fiber, their density, throughness, tensile and elongation characteristics were investigated.

According to the water analysis of in the segment of the Eshkakon reservoir, the suspension content increases with depth (Table 4):

Table 4. Indicators of the qualitative water compositio, sampling at the water intake reservoir.

\begin{tabular}{|c|c|c|c|c|c|c|c|}
\hline \multirow{2}{*}{ N } & \multirow{2}{*}{ Item name } & \multirow{2}{*}{$\begin{array}{c}\text { Measure } \\
\text { ment } \\
\text { unit }\end{array}$} & \multicolumn{6}{|c|}{ Depth. m } \\
\cline { 4 - 8 } & & $\mathbf{3 ~ m}$ & $\mathbf{1 0 ~ m}$ & $\mathbf{1 5 ~ m}$ & $\mathbf{2 0 ~ m}$ & $\mathbf{2 5 ~ m}$ \\
\hline 1 & Colour & degree & 5 & 5 & 4 & 5 & 5 \\
\hline 2 & Odor & point & 0 & 0 & 0 & 0 & 0 \\
\hline 3 & Transparency & $\mathrm{cm}$ & 16 & 25 & 19 & 17 & 16 \\
\hline 4 & PH & - & 8.5 & 8.4 & 8.5 & 8.5 & 8.5 \\
\hline 5 & Turbidity & $\mathrm{mg} / 1$ & 60 & 110 & 140 & 310 & 560 \\
\hline 6 & Hardness & $\begin{array}{c}\mathrm{mg} \text { equiv } \\
\text { / }\end{array}$ & 2.9 & 2.8 & 3.1 & 3.2 & 2.7 \\
\hline 7 & Alkalinity & $\mathrm{mg} / 1$ & 3.2 & 3.1 & 3.3 & 3.4 & 2.9 \\
\hline 8 & Temperature & $\mathrm{C}^{0}$ & 10 & 8 & 8 & 6 & 6 \\
\hline
\end{tabular}

Studies indicate needs to reduce turbidity. According to the dimension of the suspension (see table 6), the FSFD cells should retain particles of $1.0-0.03 \mathrm{~mm}$, while skipping the required flow rate of 60 thousand $\mathrm{m} 3$ / day. To implement this task in the studied water intake structure, it is necessary to determine its water permeability (filtration characteristics). The throughput capacity (water filtration) was calculated with a mesh size of $0.1 \mathrm{~mm}$ and required flow rate for consumers of 60 thousand $\mathrm{m} 3$ / day with a canvas area of $300 \mathrm{~m} 2$.The filtration rate is calculated as the filtrate volume, which passes per unit time through the filter surface (6):

$$
\mathrm{W}=\mathrm{dV} /(\mathrm{S} \cdot \mathrm{d} \tau)
$$

where:

$\mathrm{w}$ - filtration rate, $\mathrm{m} / \mathrm{s}$;

$\mathrm{V}$ - filtrate volume, $\mathrm{m}^{3}$;

$\mathrm{S}-$ filtration area, $\mathrm{m}^{2}$;

$\tau$ - filtration time, $\mathrm{s}$.

$\mathrm{W}=\mathrm{dV} /(\mathrm{S} \cdot \mathrm{d} \tau)=60$ thousand $\mathrm{m}^{3} /\left(300 \mathrm{~m}^{2} * 84600 \mathrm{~s}\right)=2,4 \mathrm{dm}^{3} / \mathrm{m}^{2} / \mathrm{s}$. 
Thus, permeability of FSFD provides consumers daily needs. Calculations showed that for given sizes of polypropylene fabric, filtration rate and water flow rate, a mesh size of $0.1 \mathrm{~mm}$ corresponds to the task - the technology of selective water intake, as applied to the Eshkakon gas transmission system is carried out.

\section{Conclusions}

Water studies of the Eshkakon reservoir confirmed presence of vertical stratification. Taken samples indicate the need to reduce turbidity. Monitoring of previous years by water analysis revealed a large suspension in the spring - summer period. The technological scheme of reducing turbidity with the help of a coagulant is calculated. With a turbidity of up to $100 \mathrm{mg} / 1$ and a flow rate of 60 thousand $\mathrm{m} 3$ / day, the consumption of coagulant is 8 1/ h (192 1/ day). For 60 thousand $\mathrm{m} 3$ / day it needs about $0.192 \mathrm{~m} 3$ / day coagulant or 70.8 $\mathrm{m} 3$ / year. At an average price on the coagulant market of 80 rubles per liter per year, 5 million 600 thousand rubles are spent on the reagent. The stress-strain state of the FSFD polypropylene fabric was calculated for various loads combinations and strength estimates were obtained from known principal stresses at design points (warp and weft). The choice between the developed device made of polypropylene fiber and the nylon fabric analogue with a rubber factory coating is economically justified. The cost-effectiveness with an analogue was 380,300 rubles / unit.

The turbidity water analysis in the Eshkakon reservoir by depth marks is given. According to the dimension of impurities of inorganic and organic origin and the quantitative content of suspended solids (according to SP 31.13330.2012 [15]), FSFD cells size was chosen $-0.1 \mathrm{~mm}$. To reduce the turbidity of the produced water, the filtration rate was calculated according to the specified parameters of the cell throughput to pass the required flow rate (60 thousand $\mathrm{m} 3$ / day) $-2.4 \mathrm{dm} 3 / \mathrm{m} 2 / \mathrm{s}$.

Based on the research results, the following was described: device itself, technological scheme of the process, main provisions on the technology, structure drawing was submitted, an application for registration of intellectual property No. 2019129750 (058568) dated 09/19/2019 was submitted - a method (invention) under consideration at the Federal Institute Industrial Property (FIPS). Title of the invention "Floating synthetic filter device (FSFD)".

\section{References}

1. N.I. Alekseevsky, N.L. Frolova, A.V. Khristoforov, Monitoring hydrological processes and improving water safety (Moscow State University, Moscow, 2011)

2. O.A. Romanova, N.L. Frolova, Water: chemistry and ecology 5, 2-10 (2011)

3. H.R. Delcourt, R.A. Delcourt, Quaternary Science Review 1, 153-175 (2011)

4. B. Hjoerland, Journal of the American Society for Information Science and Technology 61(2), 217-237 (2010)

5. T. Ivankova, International conference proceedings Collection of articles $\mathbf{9}, 7$ (2015)

6. T. Ivankova, Reporter of Donskoy state agrarian university 3-3(17), 61-71 (2015)

7. T. Ivankova, RUSAINS 186 (2017)

8. T. Ivankova, «TEKHNOVOD-2016»: IX International conf. proceedings NPI, 30-35 (2016)

9. N.I. Alekseevsky, N.L. Frolova, A.V. Khristoforov, Geography faculty MGU 408 (2011) 
10. Y. Volosukhin, T. Ivankova, Proceedings of the I International Scientific Conference KCHU, 194-199 (2019)

11. V. Volosukhin, Construction systems for water resources protection of using structures from fabric materials NGMA (2008)

12. State standard of the Russian Federation GOST R 51232-98

13. T. Ivankova, Construction and architecture 6, 9-13 (2018)

14. T. Ivankova, International Research Journal 2(80), 43-47(2019)

15. Russian Federation Code Specification SP 31.13330.2012 